\title{
IMPACT OF URBANISATION ON WATER QUALITY PARAMETERS - A CASE STUDY OF ASHTAMUDI LAKE KOLLAM
}

\author{
Nagaraj Sitaram ${ }^{1}$ \\ ${ }^{1}$ Professor, Department of Civil Engineering, SJB Institute of Technology, Uttarhalli Main Road, Kengeri, Bangalore-60
}

\begin{abstract}
The Ashtamudi Lake in the Kollam District of Kerala lies in between $76.53^{\circ}$ and $76.63^{\circ}$ longitude and $8.93^{\circ}$ and $8.83^{\circ}$ latitude. It is a palm-shaped extensive waterbody with eight prominent arms, adjoining the Kollam town. This extensive estuarine system has a length of $16 \mathrm{~km}$ with a maximum width of $14 \mathrm{~km}$ and maximum depth up to $6.4 \mathrm{~m}$ covering an area of $64.2 \mathrm{~km}^{2}$. The Ashtamudi Lake has been designated as a Ramsar Site (No.1204) in November 2002 and is also a major tourist place. It supports around 43 -marshy mangrove species, 57-species of birds, 97-species of fishes and some unique copepod species which are important sources of food. More than 20,000 waterfowl visit the lake annually. Coconut husk retting, fishing, inland navigation and a fishing harbour at Neendkara are other benefits provided by this lake. The case study describes the effect of urbanisation on water quality parameters and suggest for its improvement. The water spread area for Ashtamudi Lake in these three years are found to be shrinking (1999 - 6424 ha, 2003 - 6140 ha, 2006 - 5734 ha). The detailed physico-chemical and biological examinations are collected for three years (1999, 2003, and 2006) made during pre-monsoon season for various locations and their average values are reported. A comprehensive plan is prepared to restore the water quality of Ashtamudi Lake near the Kollam City.
\end{abstract}

\section{INTRODUCTION}

The Estuarine eco-systems in India are the most critical component of the coastal environment as it sustains millions of people and implications of its degradation is disastrous. The picturesque Ashtamudi Lake in Kollam District is one of the deepest and largest wetland ecosystems of Kerala State. The shores of Ashtamudi Lake are home to thousands of Kollam District's population. The main functions of a City lake can be described on various fronts such as to provide environmental services like flood prevention, pollution reduction, fishing and wild life protection, support to species diversity, recreation and aesthetics (Tourism), ferry and cargo services etc. The Map of Ashtamudi lake showing important features are given in Fig.1. The population of Kollam City is 361,440 and is likely to grow to up to 400,000 by 2031 . The rapid growth of
Kollam City due to establishment of new Goverenment offices and Industrial projects (Neendakara Port and Titanium Complex projects) have inreased the pollution load on the Ashtamudi Lake. The Lake plays a vital role in the socioeconomic and cultural history of the State besides constituting an invaluable aesthatic resource.

The Ashtamudi Lake being used as common property resources and are openly accessible to all Every one claims a stake in their use, but few are willing to pay for the extractive use. 


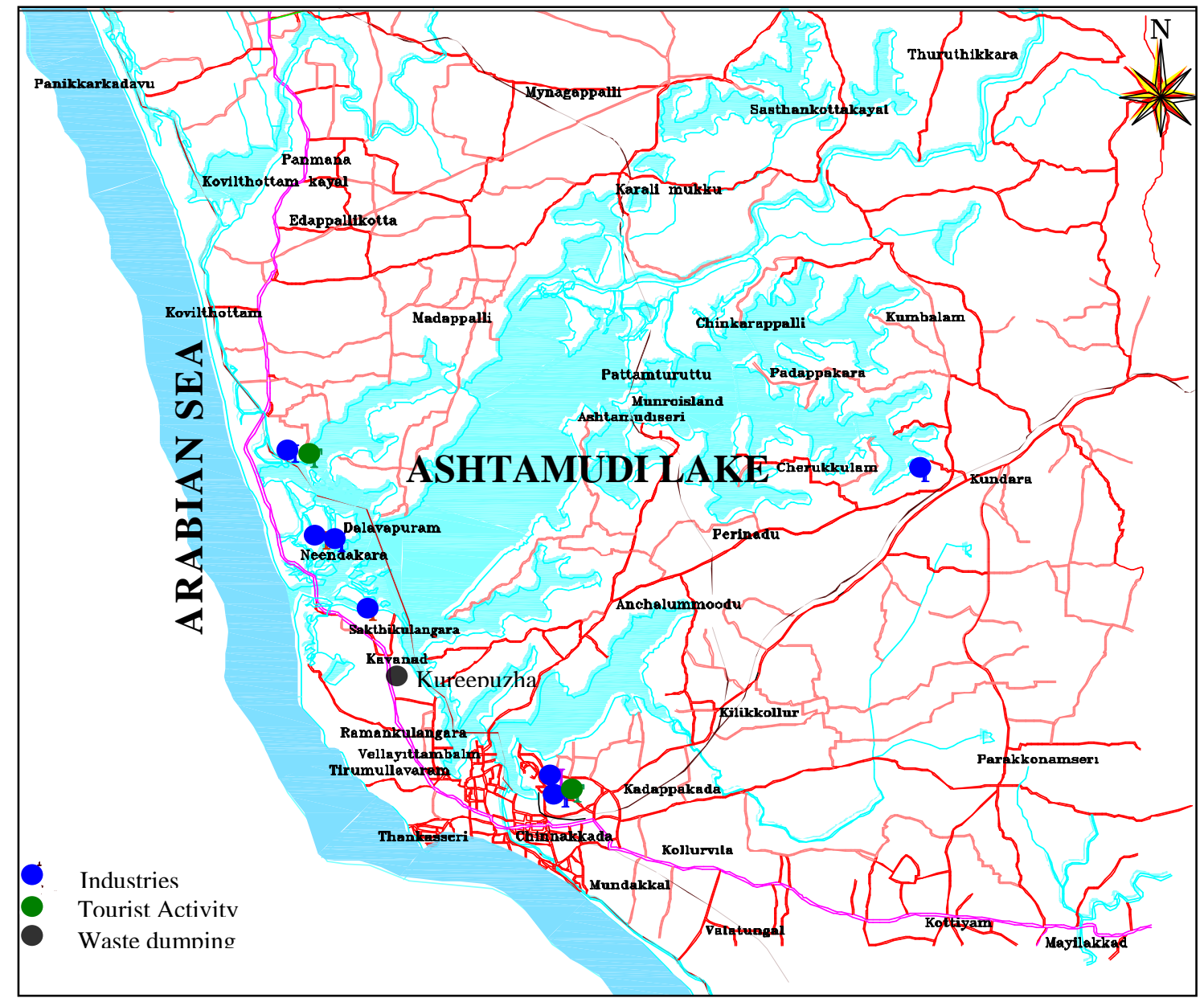

Fig.1 Map of Ashtamudi lake (Kollam, Kerala)

\section{DEGRADATION OF ASHTAMUDI LAKE:}

The water quality of Ashtamudi Lake is deteriorating specifically in the reach joining the site with built up area of Kollam city, TS Canal and Kallada River. It currently receives all untreated sewage from the Kollam city, direct disposal of human excreta from hanging latrines and household waste. The foreshore areas of this Lake are reclaimed for coconut plantation and construction purposes resulting in the shrinking of lake. The microbial contamination is high in some locations particularly around the port area and in the Kallada River zone (Asramom, Perumpe, Vincent Thuruthu). The agricultural practices warrant the use of chemical/organic fertilizers and insecticides/pesticides, and the residual flow in to the lake causing pollution and Water Eutrophication (Increase of $\mathrm{N}, \mathrm{P}, \mathrm{K}$ ) (Aravind Kumar,2006). The Southern portion of Ashtamudi Lake is affected by waste disposal from the Coconut husk retting, Ceramic, Paper and palm oil industries, Tourism activity, Cashew factories and hospitals which resulted in the increases of bioaccumulation of sediments and heavy metals. The untreated effluents from small-scale industries, unscientific methods of fishing, food processing units, boat building yards,

oil spillage and slaughterhouses makes the situation even worse $(\mathrm{N}$. Balakrishnan Nair, 1989). Fig. 2 shows the schematic diagram of sources of pollution in Ashtamudi Lake. The water quality parameters are analysed for DO, pH, and Heavy metals (Fig. 3 and Fig. 4) over a period of 7-years and it was found that the quality of water in Ashtamudi Lake is deteriorating at faster rate. The Kerala State Council for Science Technology and Environment (KSCSTE) has suggested a comprehensive plan to improve the water quality and sustainability of Ashtamudi Lake. 


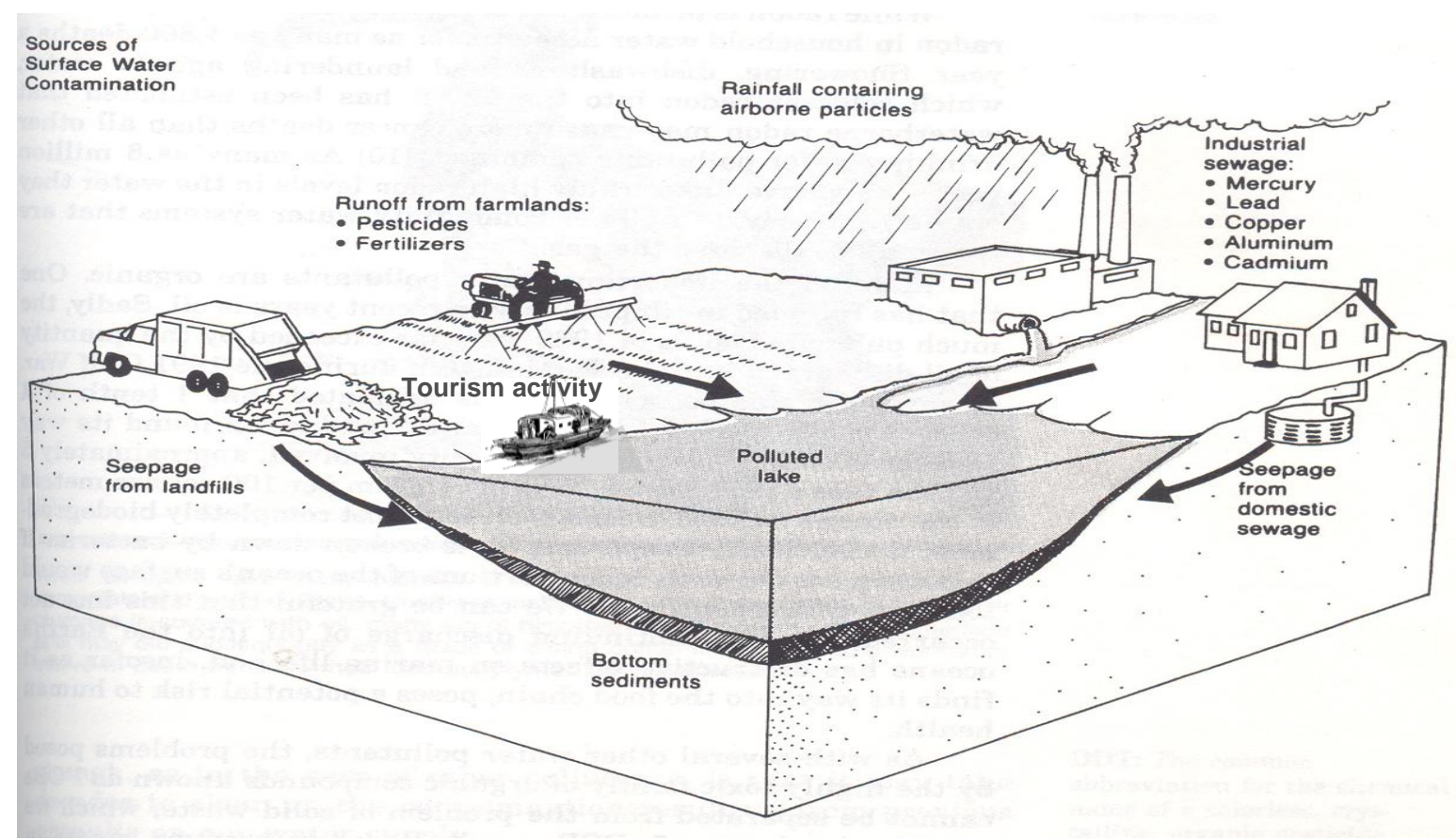

Fig.2 Schematic Diagram Showing Sources of Pollution for Ashtamudi Lake

Following are the reasons for the deterioration of water quality parameters in Astmaudi Lake

Reclamation of Ashtamudi of Lake: The Human interventions, during the past years have resulted in reduction of water spread area in Ashtamudi Lake (Table-1). The lake is reclaimed for various purposes like agricultural expansion, aquaculture practices, coir retting, harbour development, urban development and other public and private uses. Dumping of urban wastes is also reclaiming South end of the Ashtamudi Lake near the Asramam region. Most of these reclamations are for agricultural, housing and paddy-cum shrimp culture cultivation. The islands being enlarged in the entrance zone using sands, dredged from the National Waterway (NW-3) channel, which in turn is diverting the main flow and changing the flushing characteristics of southern and central portion of Ashtamudi Lake. It has been reported that the dumping from the clay mines has reclaimed about $3-\mathrm{km}^{2}$ of estuary during 25-years.

Table-1 Area of Ashtamudi Lake during 1999-2006

\begin{tabular}{|c|c|c|}
\hline Year & $\begin{array}{c}\text { Lake Area } \\
\left(\mathrm{Km}^{2}\right)\end{array}$ & $\begin{array}{c}\text { \% Area } \\
\text { Reclaimed }\end{array}$ \\
\hline 1999 & $\mathbf{6 4 . 2 4}$ & - \\
\hline 2003 & 61.40 & 4.42 \\
\hline 2006 & $\mathbf{5 7 . 3 4}$ & 10.74 \\
\hline
\end{tabular}

Pollution due to Coir retting: The waste disposal of coconut pith is having a major impact on bottom sediments and results in reduction of Dissolved Oxygen, which impacts negatively on fish and overall health of water body. The coir retting also causes organic pollution of the Lake, resulting in release of large quantities of organic substances like pectin, fat and tannin into the water by activity of bacteria and fungi. The decomposition of pectin results in the production of hydrogen sulphides producing nauseating smell in and around retting zones. A High organic content (6\%-13\%), high BOD $10 \mathrm{mg} / 1$ (safe limit $3 \mathrm{mg} / \mathrm{l}$ ), low oxygen $0.05 \mathrm{mg} / \mathrm{l}$ (safe limit $4 \mathrm{mg} / \mathrm{l}$ ) and high sulphide $(4.97 \mathrm{mg} / 1)$ characteristic are found near the retting zones of Ashtamudi Lake, which is affecting the flora, and fauna of the lake.

Industrial Pollution: The Ashtamudi region is well endowed with natural resources (e.g. rare earths, clays, raw product) and lake's vicinity with Kollam City (e.g. connections to highways, waterways, fishing port facilities) have resulted faster industrial growth. The major industries which release effluents to Ashtamudi Lake are Kundara Ceramics (clay products), Indian Rare Earths Ltd (mineral extraction), Kerala Metals and Minerals Ltd (mineral extraction), Kerala State Cashew Development corporation Ltd., Aluminium Industries Kundara etc. In addition to this there are many small-scale units like fish processing, seafood units, motor and welding workshops functioning adjacent to the lake area. These effluents contain a large number of toxic ingredients such as acids, alkali, heavy metals, suspended solids and a number of other chemicals, which have immediate and long-term effects on the organisms. The industrial locations in the vicinity of Ashtamudi Lake are marked in the Fig. 1. 
Agriculture: Agriculture expansion accompanied by intensive use of agro-chemicals has become a major driving force for encroachment, reclamation, pollution, water eutrophication, and biodiversity-loss for the Ashtamudi Lake. The fertilizers used for the crops are seeping to the lake, which causes pollution.

Aquaculture: Like agriculture, aquaculture has also various dimensions and scales of operation in the lake and has become a driving force for pollution, water eutrophication, encroachment, and biodiversity loss. Most of the aquaculture farms are use commercially available organic and inorganic feeds and artificial techniques for filtration. Aquaculture is having a localized impact on water quality by increasing the salinity and discharge of wastes of the surrounding water, but no other strong chemical signature was identified, even though discharges associated with organic waste are often present at aquaculture sites (Velayudhan T S, Kripa V and Narasimhan K A, 1995).

Fishing: Fishing in Ashtamudi Lake is one of the major economic activities. Good water quality and compatible uses of the water body are essential for the continued sustainable use of Ashtamudi as a source of fish. Over-exploitation of the fishery resources is a major threat to the Ashtamudi Lake. The efficiency of the fishing is improving due to use of modern equipments. There has been a loss of mangrove habitat and changes to the marine foliage due to pollution of lake along the shoreline that have affected the fish stocks and fish quality in recent years (J V Thomas and B M Kurup, 2007).

Water Transport: The water transport system is intended for providing facilities for passenger, tourist and cargo transportation at cheaper rates. Mechanized luxury boats, both Government (State Water Transport Department) and private operate from the main boat jetty (near Bus Stand Kollam) during all seasons. Ashtamudi Lake in the north and the Paravur Kayal in the south are connected with TS Canal, which form the inland water network. The National Waterway (NW-3), which lies between Kollam and Kottapuram, is passing through Ashtamudi Lake. The Water Transport Department operate regular boat services to Muthiraparamb (West Kallada), Guhanandapuram, Ayiramthengu, Munrothuruthu and Alappuzha. Incidents of poor handling of fuel have led to oil spillages in lake water. Outboard engines exhausts are creating hydrocarbon/fuel pollution. Increase in number of houseboat operation has also lead to more direct discharge of sewage to the lake (P. Anoop et al, 2007).

Tourism: Foreign tourists in Kollam District comprised 4\% and $3 \%$ of the State's foreign tourist population in 2002 and 2003, respectively; the corresponding figure for domestic tourists is $2 \%$ in both years (C K Sasidharan and $\mathrm{P}$. Sivanandan, 2007). Cruise operations and traditional houseboats operate from Kollam towards east up to Munrothurthu and towards north up to Alappuzha.
Speedboats operate in Asramam Kayal, which is the Southern part of Ashtamudi Lake. The unimpeded tourism activities contribute significantly to pollution, which has accelerated water eutrophication, encroachment, reclamation, mining and biodiversity loss.

Sand Mining: Sand mining is presently conducted in the Kallada River zone and along the northern shore of Ashtamudi lake. The sand mining activity will lead to deepening of the riverbed, which will reduce the natural filtering capacity of river. In addition it will increase the rate of bank erosion and saline water intrusion. The present rate of mining of the eastern Kayal may not be sustainable due to a lack of sediment output from the Kallada River. The estuary is primarily infilling from the sea. The entrance and western portion of the Ashtamudi Lake is shallow and sand rich. For the marine ecology, it is beneficial to mine from the specific areas for 1-2 seasons and then to move to another site, rather than mining from the same area. This allows most of the habitat to remain intact and provides a suitable recovery time of the areas being mined. Shell mining is another livelihood activity dependent on the estuary, which is largely located in the Central portion of Ashtamudi Lake.

Municipal Waste Disposal: Municipal solid waste (solid as well as domestic) and sewage from Kollam Municipal Corporation are one of the major sources for lake pollution as it uses the Ashtamudi Lake as a 'waste sink'. It is estimated that the latrines (including the hanging ones) of about $60 \%$ of houses near the lake are directly discharging into the lake. Unfortunatley the waste-dumping yard of Kollam Municipal Corporation is also located very close to the banks of the Southern Kayal at Mammoottikkadavu (Fig.1). The Hanging toilets are common at the entrance region, southern and central portion of the Ashtamudi Lake. Mammoottikkadavu, near Kollam Bus Stand and Kureepuzha are the other waste dumping sites for disposing untreated waste to lake. It also contains large quantities of non-degradable plastic bags and containers. There is no proper management practices for disposing the waste from slaughterhouse and hospital in the city.

\section{WATER QUALITY AT ASHTAMUDI LAKE}

The water quality condition of Ashtamudi Lake is worsening due to various socio-economic activities described above. The water quality parameters are collected over the years at various locations and data is analysed to describe the health condition of Ashtamudi Lake. The dissolved oxygen (DO), which is one of the indicators for avialability of oxygen in water body, is found to be decreasing over the years (Table-2) and it is alarming in certain pockes of Ashtamudi Lake. This indicates that environmental degradation is occurring. The average DO levels in the Ashtamudi average $3.2 \mathrm{mg} / \mathrm{l}$ in the non-monsoon compared to the values of about $5 \mathrm{mg} / \mathrm{l}$ in a healthy tropical water body. The Low levels of DO $(2-3 \mathrm{mg} / \mathrm{l})$ 
occur in the Southern portion of Lake adjacent to Kollam City (Fig.3, 6). The Chemical pollution of water is not high except in certain pockets, but maximum chemical concentrations typically occur at the landward ends of the Lake and near the entrance to the estuary. Chemical pollution in bottom sediments is severe in places, particularly in the southern portion of Ashtamudi Lake. The eastern Lake has best water quality overall and lowest turbidity and coliforms. Microbial contamination (E-coli (2500 MPN/100ml) and Faecal Coliform (1800 MPN/100ml)) are high at some locations, particularly around the port area (Chavara, Neendakara) and in the River zone. The water quality of southern lake is affected by waste disposal of the Coir industry, which causes a large increase in bed sediment organic content. There are areas of localized increase of salinity (up to $35.2 \mathrm{ppt}$ ) near the aquaculture sites, but salinities remain below the typical seawater values $(4.5 \mathrm{ppt})$. Flushing of the lake is slow and so discharges to the water body need to be minimized. A chemical signature of inland industrial development is evident in the eastern, particularly in southern and western portion of Ashtamudi Lake. Polluting hydrocarbon content is highest in the fishing harbour area and along the National Waterway (NW-3). The spatial distribution of dissolved oxygen and mercury are shown in Fig. 3 and Fig.4. The variation of parameters like $\mathrm{DO}, \mathrm{pH}$, mercury and cadmium are given in Table-2 and Fig. 5 and Fig. 6.

Table- 2 Variations of Water Quality Parameter in Ashtamudi Lake

\begin{tabular}{|c|c|c|c|c|}
\hline \multirow{2}{*}{ Year } & \multicolumn{3}{|c|}{ Water Quality Parameter (DO,pH and Heavy Metals) } \\
\cline { 2 - 5 } & Permissible values : DO > 4.0 mg/l, pH : 6-8.5, Mercury <0.001mg/l, Cd<0.01mg/l \\
\cline { 2 - 5 } & DO & pH & Mercury & Cadmium \\
\hline 1999 & 3.8 & 7.8 & 0.16 & 0.225 \\
\hline 2003 & 3.4 & 8.1 & 0.23 & 0.230 \\
\hline 2006 & 2.5 & 8.1 & 0.29 & 0.260 \\
\hline
\end{tabular}
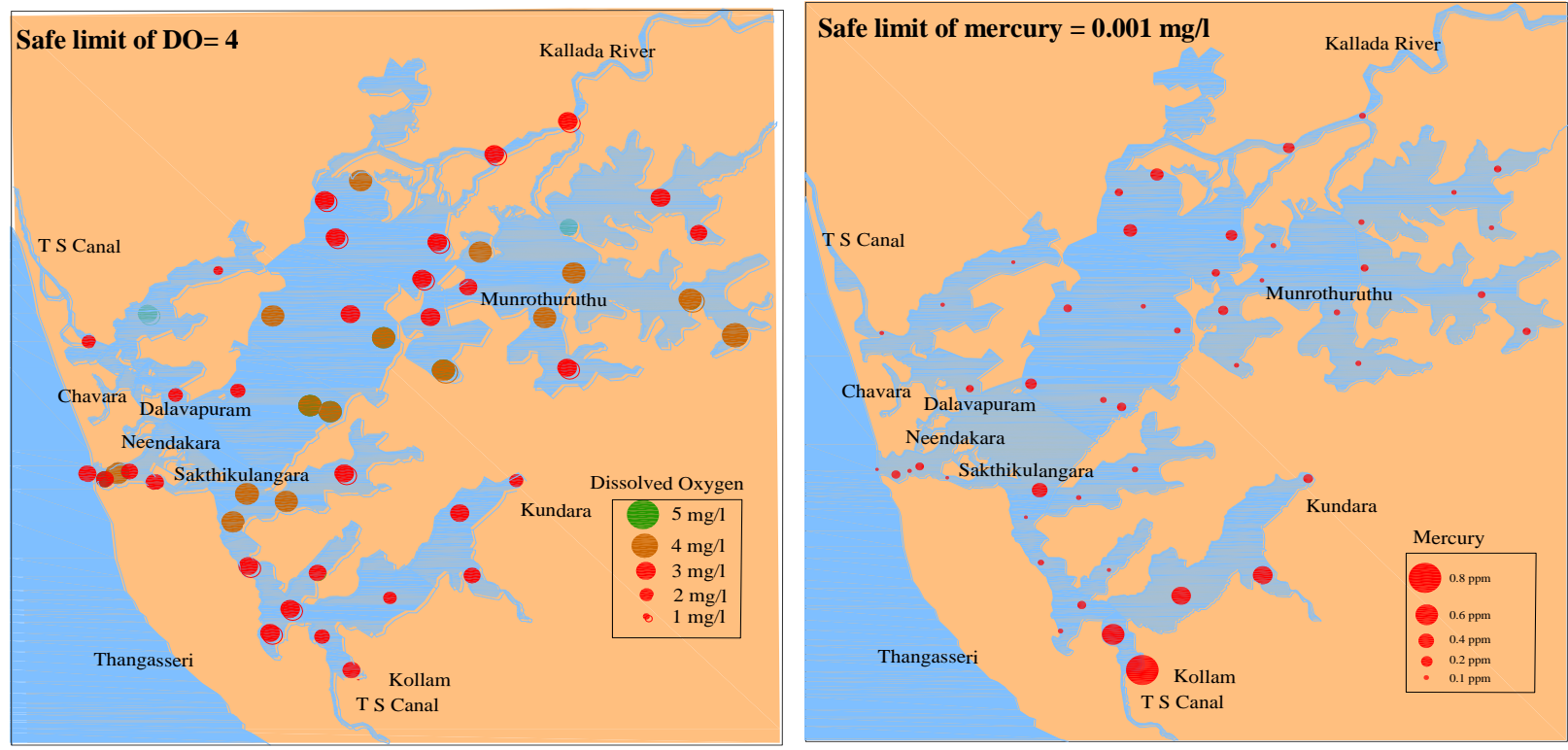

Fig.3 Distribution of Dissolved Oxygen (2001)

Fig. 4 Distribution of Mercury (ppm) (2001)

Fishing is the major activity in the Ashtamudi Lake. Aquaculture activities like prawn culture, mussel culture etc are also common. Legal and illegal sand mining is on the rise in estuary as well as the river channel. There are 88-water supply (7-Urban and 81-Rural) projects in the district; most of them are sourcing water from the Kallada drainage basin (KSCSTE, 2007). 

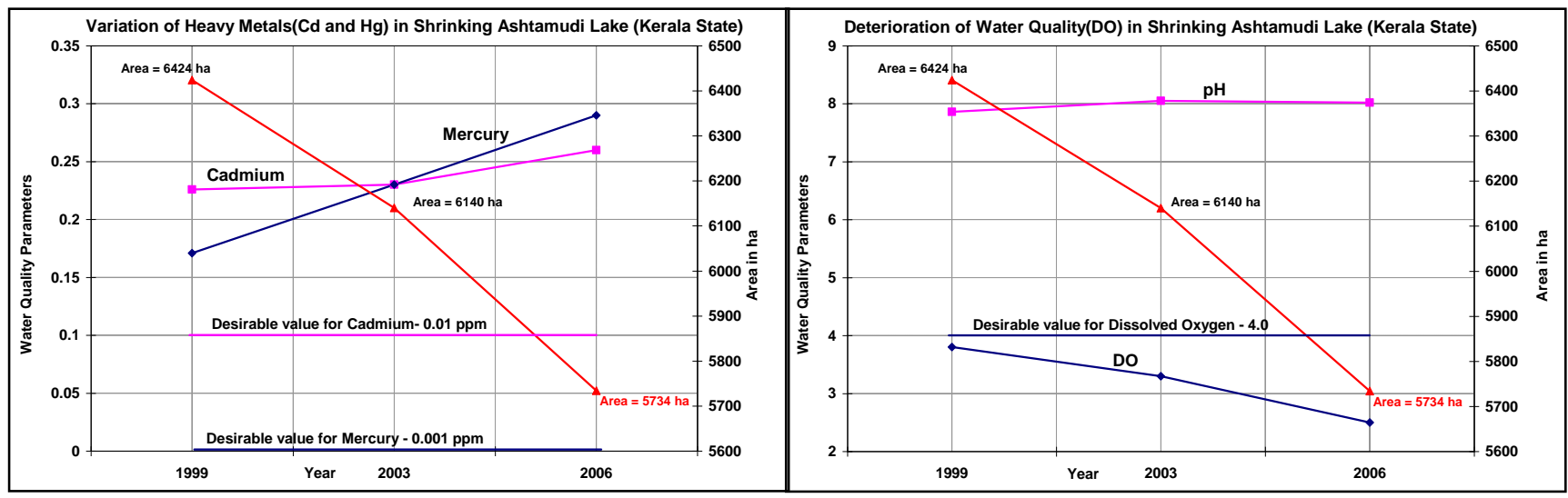

Fig 5 Increase of concentration of heavy metals Fig 6 Variation of $\mathrm{pH}$ and Dissolved oxygen In Shrinking Ashtamudi Lake (1999-2006) in Shrinking Ashtamudi Lake (1999-2006)

\section{ASHTAMUDI MANAGEMENT PLAN (AMP):}

The decline of water quality and biodiversity observed in Ashtamudi Lake of Kollam City provides sobering evidence that neglect of urban water bodies and their catchments, and with rapid increase in population, the cities are on the verge of collapse. The restoration of Ashtamudi Lake is to be taken on a war footing (on a project basis), followed by a post-project monitoring. By keeping the above facts in mind, The Kerala State Council for Science Technology and Environment (KSCSTE) have suggested a comprehensive plan to improve the water quality and sustainability of Ashtamudi Lake. All the stakeholders of Ashtamudi Lake whose activity affects the quality of lake water are included in the restoration plan as active partners. Each of the stakeholders is consulted and represented in the development plan.

A Management Plan (Kerry Black and M Baba, 2001) to guide and sustain the future of the Ashtamudi Estuary, Kerala India, was developed with funding support from the Asia Development Assistance Facility of the Ministry of Foreign Affairs and Trade, New Zealand through the joint efforts of Center for Earth Sciences Studies (CESS), South India Federation of Fisherman Societies (SIFFS), Centre for Development Studies (CDS), Panchayaths surrounding the lake. The methodology of the study has proved to be highly successful. The Key facets were:

$>$ Participatory through the adoption of a local steering committee and public input,

$>$ Multi-disciplinary (social, economic, gender, fisheries, physical, environmental, chemical and planning aspects) data collection and involvement of many experts;

$>$ Colourful, readily available and wide distribution of results through several media

$>$ Close working relationship with the Stake Holders of lake
The efforts are to be made to improve the water quality through management of discharges, industry growth, the port, vessels and the coir industry. Marine plants are to be planted and encouraged to promote a rise in the DO levels. The domestic sewage inputs to the lake are to be phased out, as the Faecal Coliform levels are very high (500-2500 MPN/100ml) at many places and need to be reduced. A new sewage treatment plant for the Kollam City is suggested at Kureepuzha to treat 44.0 MLD. Future reclamation is to be prohibited in the estuary. Beneficial uses for the dredged sand, e.g. open beach and foreshore coastal protection, sand mining should be found out. Alternatives (value added product) for the use of coir pith are to be invented. Planting of mangroves should be encouraged for the re-establishment of sites where they were present in the past. A study with numerical modeling should be undertaken to find the optimal alignment for the National Waterway channel, which will minimize maintenance dredging while also satisfying navigation, fishing and other livelihood activities in accordance with the CMP. Sand Mining should be prohibited at any sites, which are too close to the estuarine bank. The fast boats are restricted to a region associated with focused tourist development. The houseboats have to provide with holding tanks or chemical toilets for sewage and that the tanks be emptied offshore or to a central treatment facility, not in the inland water. Channel markers are to be placed to show boat pathways and fast boat region. Periodical inspection of exhausts and fuel handling should be done. A central facility for docking and emptying of sewage is to be constructed. The stake nets strung across the entrance and used through out the estuary must be no finer than a chosen minimum mesh size. Minimum mesh sizes should be set in consultation with fishermen and biologists. Undertake training through local bodies about aquaculture farm management. The vision for tourist development should be eco-based with a focus on water activity. New Tourist destinations, which are eco-friendly, should be encouraged for further development Example: The Vellimon Kayal (Eastern part of Ashtamudi Lake). A houseboat destination and nature 
park should be developed on the uninhabited Palliathuruthu Island in the eastern part of lake. A mangrove Conservation and Seed Propagation area should be established near the mouth of the Kallada River joining the Ashtamudi Lake.

Sustainable measures for Restoration of Ashtamudi Lake: Socio-economic dimensions are crucial to the sustainable management of environmental resources. Natural habitat faces serious degradation including reclamation of the estuary. Therefore, it is essential to have a long-term management plan for water resources. The action plan for sustainable restoration of Ashtamudi Lake is summarized in Table-3 below:

Table - 3 Plan of Action for Ashtamudi Lake Restoration

\begin{tabular}{|c|l|l|}
\hline $\begin{array}{c}\text { Sl. } \\
\text { No }\end{array}$ & \multicolumn{1}{|c|}{ Plan of Action for Ashtamudi Lake Restoration } & \multicolumn{1}{|c|}{ Area Identified } \\
\hline 1 & $\begin{array}{l}\text { Pollution sources are identified and priority list is prepared: Plan action to } \\
\text { reduce the pollution load in Ashtamudi Lake after consulting each } \\
\text { stakeholders }\end{array}$ & $\begin{array}{l}\text { Kureepuzha, Kundara, } \\
\text { Kadappakkada, Neendakara }\end{array}$ \\
\hline 2 & $\begin{array}{l}\text { Mangrove conservation-cum-rehabilitation in areas near the confluence point } \\
\text { of the Kallada river and the Ashtamudi lake. }\end{array}$ & $\begin{array}{l}\text { Kallada, madappally, } \\
\text { Mundrothuruthu }\end{array}$ \\
\hline 3 & $\begin{array}{l}\text { Reclamation of lake area is to be halted } \\
\text { Neendakara,Mundrothuruthu }\end{array}$ \\
\hline 4 & $\begin{array}{l}\text { The continuation of small-scale sand mining is recommended near the } \\
\text { villages but the sustainable volume need to be determined based on the } \\
\text { deposition rate. }\end{array}$ & $\begin{array}{l}\text { Area Recommended are: West } \\
\text { Kallada, East Kallada, } \\
\text { Padappakkara }\end{array}$ \\
\hline 5 & $\begin{array}{l}\text { Upgrade the sanitation facilities, boat fuelling area and better drainage } \\
\text { systems near the lake to keep the fish quality at its best for local food and } \\
\text { export }\end{array}$ & $\begin{array}{l}\text { Kureepuzha, Kadappakkada, Neendakara } \\
\text { Kadandara }\end{array}$ \\
\hline 6 & $\begin{array}{l}\text { Continue coir retting, but phase out discharge of waste pith back to the water. } \\
\text { Alternative waste disposal sites and waste by-products will be identified. }\end{array}$ & $\begin{array}{l}\text { Area Recommended } \\
\text { Padappakkara, Mundrothuruthu }\end{array}$ \\
\hline 7 & $\begin{array}{l}\text { A comprehensive public awareness programme is to be conducted to improve } \\
\text { the aesthetic environment near the Lake }\end{array}$ & $\begin{array}{l}\text { To be organised at Schools, } \\
\text { Community Halls }\end{array}$ \\
\hline 8 & $\begin{array}{l}\text { Provide a solid waste disposal system in the neighbouring area of Ashtamudi } \\
\text { Lake. It is suggested to Kollam municipality to use a two-bin system for the } \\
\text { disposal waste }\end{array}$ & $\begin{array}{l}\text { A solid waste dumping yard is } \\
\text { suggested at Kureepuzha(44.0 } \\
\text { MLD) }\end{array}$ \\
\hline
\end{tabular}

\section{CONCLUSIONS}

The Ashtamudi Management Plan has initiated the participation of all the stakeholders that include primarily the dwellers (e.g., Resident associations, Fisherman and NGO's) and tourists in and around the lake who derive benefits from it, Government departments. The point and non-point sources of pollution are identified. The management action plan is drawn (Table-3) to alleviate the growing burden of environmental degradation of the Ashtamudi Lake. The water quality data analysed over the years show a negative trend in water quality parameters. The Dissolved Oxygen (DO) value, which represents the health of the lake, is less than $4.0 \mathrm{mg} / \mathrm{l}$. The heavy metal concentration, E-coli count and TDS are above the prescribed limit. It is highly recommended to implement the actions suggested by Ashtamudi Management Plan to restore the water quality of Ashtamudi Lake. Regular awareness camp, training program for the general public and meetings amongst the stakeholders should be arranged in Kollam City to monitor the progress of the Lake restoration plan.

\section{ACKNOWLEDGEMENTS}

The authors express their gratitude towards the Executive Vice President, KSCSTE, Trivandrum for publishing the research paper

\section{REFERENCES}

[1] Sasidharan C. K. and P. Sivanandan, Focus on Resource Management Issues for Eco tourism Development - A Case Study of Ashtamudi Estuary, Taal 2007, 12 $2^{\text {th }}$ World Lake Conference, 2007

[2] Thomas J.V. and B M Kurup, Pedal Fishing - A unique fishing method in the Ashtamudi Estuary of Kerala (South India), 2007

[3] Kerry Black and M Baba, Ashtamudi Management Plan-Developing a Management Plan for Ashtamudi Estuary, Kollam, India, August 2001

[4] KSCSTE, State of Environment Report-Kerala, Land Environment wetlands of Kerala \& environmental health, Volume 1, 2007

[5] Nair,N.Balakrishnan and et. al; Ecology of Indian estuaries VII "Inorganic nutrients in the Ashtamudi 
estuary" Dept. Aquatic Biology Univ. of Kerala, Trivandrum, Mahasagar,17(1),19-32., 1989, India.

[6] Anoop P. et al, Economic evaluation of use benefits of Ashtamudi Estuary in South India, Taal 2007, 12 World Lake Conference, 2007.

[7] Velayudhan T S, Kripa V and Narasimhan K A.,. Experimental culture of $\mathrm{C}$-madrasensis (Preston) at Ashtamudi Lake, Kerala. Seafood Journal, Vol XXVI, 8: $5-14,1995$. 